\title{
The Most Suitable Way of Teaching
}

\author{
Efrosyni-Alkisti Paraskevopoulou-Kollia* \\ University of Thessaly Department of Computer Science and Biomedical Informatics \\ Papasiopoulou 2-4, 35131, Lamia, Greece \\ E-mail: frini@dib.uth.gr \\ Christos-Apostolos Michalakopoulos \\ University of Thessaly Department of Computer Science and Biomedical Informatics \\ Papasiopoulou 2-4, 35131, Lamia, Greece \\ E-mail: michalakopouloschristos@gmail.com
}

\section{This research received no external funding (Sponsoring information)}

\begin{abstract}
Within the context of educational science it is necessary to deal with ways of making the transmission of knowledge to individuals more effective. In trying to find out which is the best way of teaching K-12 curriculum (that is how publicly supported education from kindergarten to High school is called in most countries), we asked our samples, which consists of eighteen (18) nursery (or pre-education) teachers, twenty five (25) primary teachers, fourteen (14) IT (or Computing) teachers and nine (9) secondary teachers, one simple question "Which is the most suitable way of teaching according to your opinion?". The research background consists of educators' efforts to comprehend ways of effective and functional teaching through the years. The method of our research is qualitative and the tools we use adopt elements from semi-structured e-mail interviews and discourse analysis. Expressing themselves in various ways, teachers ended up stating that the most suitable way of teaching is Group collaborative teaching/learning. We could claim that all teachers participating in our research try to match their teaching method to pupils' needs and that is an essential and strong element. What makes the topic significant is the fact that how to teach is an issue that concerns educators (and not only) worldwide and since aspects are numerous and not always conclusive, it is interesting to highlight them and constantly study educational reality.
\end{abstract}

Keywords: Way of Teaching; Didactics; Teachers; Qualitative Research

DOI: $10.7176 / \mathrm{JEP} / 12-29-02$

Publication date:October $31^{\text {st }} 2021$

\section{Introduction}

Within the context of educational sciences, "Didactics" is included (Federici, Russo, Tafuri, \& Pezzella, 2021; Canevaro \& O'Rourke, 2020; Tejedor et al., 2019; Grando et al., 2018; Uljens, 2004; Vosniadou, De Corte, Mandl, \& Glaser, 1996), and thus, meaning the teaching process involving the transmission of knowledge to individuals, it is necessary to understand how this transmission will be more effective.

Before starting our research, we looked for similar research projects conducted in Greece and found out that nothing official existed. So we decided to attempt finding which is the most suitable way of teaching for Greek teachers.

The didactic process involves three elements: the teacher, the pupil/student (sometimes we will be using the one or the other term, when needed in our text) and the subject being taught, that is the so-called teaching triangle (see also D'Souza, Nikku, \& Field, 2021; Friesen \& Osguthorpe, 2018), in which we should clearly take into account the interactions among them.

Didactics combines theory with the practice of teaching and mediates between the present and the future, between "being" and "having to", so that the purpose of education can be determined and the requirements of the educational process that students need so as to become familiar with it can be met (see also Koulaidis \& Kouzelis, 1990, in Matsagouras, 2006, p. 129).

Over the last few decades, many scholars have been studying and investigating how teachers teach in order to communicate information and knowledge more effectively to pupils/students (Retnawati, Djidu, Kartianom, \& Anazifa, 2018; Bambaeeroo \& Shokrpour, 2017; Brookhart, 2011; Fullan, 1993; Geddis, 1993), so that the latter can understand information and knowledge via an open and libertarian way by participating in the whole procedure. Learning transformation, practices with reference to social reality, curricula, knowledge-building strategies and understanding of learning processes, the teaching contract/relationship and socio-cognitive conflict are concepts that are included in a first attempt to approach the concept of teaching. In modern society, people, and especially the educator, must be aware of the power relations, politics and structures, and the conflicting relationships between the sexes and the social classes (Bukor, 2015; Van der Heijden, Geldens, Beijaard, \& Popeijus, 2015). Regardless of the learning theories applied, which may be the first basis for supporting teaching 
practices and techniques, it is imperative to promote critical pedagogy (Markham, 2019; Rodd \& Sanders, 2018; Stovall, 2006; Sleeter \& McLaren, 1995). It is well established that critical pedagogy actually enables the pupil/student to be transformed into an active subject, who acts without stereotypes and prejudices.

In addition to the above, it is important that teachers, as conductors, but also as "co-fellows" of the classroom journey, have the opportunity to appear flexible not only in relation to the teaching practices that they use (Panzavecchia, 2020; Fletcher, Mackey, \& Fickel, 2017; Errington, 2004; McBer, 2001) within a teaching room, but also to their chosen cognitive material that is available which is clearly placed within general ideological and philosophical movements (Cochran-Smith \& Fries, 2001; Green, 2000).

In recent years, the teaching and learning process has changed and is being reshaped on a daily basis (Cavanaugh, Dawson, \& Ritzhaupt, 2011; Fairman, 2004; Windschitl \& Sahl, 2002), increasingly integrated into the Society of Information. It is an integration that is almost uninterrupted since the evolution of Computer Science and ICT and their application in the field of education can't be unaffected by the use of technology in all areas of our lives.

The ultimate aim of teaching is nowadays the interdisciplinarity between the various scientific subjects (Jernes, Knaben, Tungland, \& Alvestad, 2020; Zuo \& Zhao, 2018; Komis, 2006, 2004). As mentioned above, in order to be able to offer knowledge in the most appropriate way, teachers should rely upon an appropriate theoretical framework, a common theoretical body, that is to say, some basic principles, on which they would be able to choose how to act in classroom.

Zeichner \& Liston (2013) referred to "the conservative tradition of teaching", "the progressive tradition", "the social-justice approach" and "the spiritual-contemplative tradition of teaching". Schwab (1970), as cited in Hlebowitsh (2012, p. 2) explained that if we tried to define which are the best "teaching contexts" we would end up agreeing that this is something rather uncertain. In Greece we could not find elements that would cover enough and focus on our research question ("Which is the most suitable way of teaching"). Some interesting research can be found in 2007 Mpotsoglou, Kakana \& Chatzopoulou who conducted research on 131 Nursery teachers but that research referred to their opinion only on Collaborative teaching and in 2015 Athanasiou who wrote about constructivism in teaching. Searching about teaching ways we came across Martin, Kolomitro \& Lam (2014) who mention these training methods: case study, games-based training, internship, job rotation, job shadowing, lecture, mentoring and apprenticeship, programmed instruction, role-modeling, role play, simulation, stimulus-based training, and team-training and Selwyn (2012, in Taylor, Breed, Hauman, \& Homann, 2013) highlighted the role of technology (of course we all enormously understood this role due to Covid-19) which enables them to get more interested in learning at some point (see also Kazu \& Issaku, 2021; Solano, Cabrera, Ulehlova, \& Espinoza, 2017; Lazar, 2015). We must always remember that there is no general teaching theory ( see also Dimitriadou, 2016; Paraskevopoulou-Kollia, 2016; Matsagouras, 2006) to be adopted within a teaching room and teachers tend to follow their personal theory (Maaranen \& Stenberg, 2020; Handayani, 2017; Matsagouras, 2006) as much as they are allowed to do it by the educational system in each country. Also, we should remember that there is no unique way or teaching method that could master in all-the-classroom interactions (Sajjad, 2010; Stigler \& Hiebert, 2009). Of course all the above should be actualized as part of a code of a deontology which will always support the right access to knowledge (Strier \& Shechter, 2016; Parr et al., 2014;).

\section{Materials and Methods}

2.1 Collecting Data, the Method

Our sample was a non-probability sample and the sampling strategy we followed was that of the sample of convenience as it consists of people to whom we had direct or indirect access (Isari \& Pourkos, 2015; Papageorgiou, 2015). The only criterion for selecting the research participants was them being active teachers of any educational level (except higher education) teaching in Greek school/s. We chose by this criterion our sample because we wanted to collect as more answers as possible and of course because we wanted to hear the "voices" from as more as possible teachers.

After collecting our sample we divided the participants into categories based on the level served, and the following four (4) categories emerged: Kindergarten teachers, Primary school teachers, Primary and Secondary school informatics teachers, Secondary school teachers (then these categories will be the four basic codes of our analysis). We chose categorizing the sample this way, because we wanted to present the results of our research per educational level,- based on the Greek educational system. We would like to note that informatics teachers can serve at the same time in both primary and secondary education level.

In the category by designation "Kindergarten teachers" we included people from our sample who served in kindergartens, regardless of gender, age and work experience. In the category by designation "Primary school teachers" we included from the sample, people who served in elementary schools and were teachers no matter of gender, age and work experience. In the category called "Primary and Secondary school informatics teachers" we included people from our sample who served in primary education and/or in secondary education and taught 
the computer science course, regardless of gender, age and work experience. In the category called "secondary school teachers" we included people from our sample who worked in secondary school, no matter of gender, age, work experience and course they were teaching.

Namely, our sample consists of eighteen (18) nursery (or pre-education) teachers, twenty five (25) Primary school teachers, fourteen (14) IT (or Computing) teachers and nine (9) Secondary school teachers, which sums up in sixty six (66) educators in total. We asked them one simple question ("Which is the most suitable way of teaching according to your opinion?") and this question was either sent and replied via e-mail or answered in writing. Data collection took place from May 2018 to May 2019 in Greece.

At first, for each category, data were processed separately and coded by colour as follows: on the first time a teaching method appeared in a participant's response, we highlighted it with a colour of our choice (either Italics or Bold or underlined for our own convenience) and each time this way of teaching reappeared we consistently highlighted it the same way. Furthermore, within each category we noted the answers that drew our interest, as also the unique answers. In this way we gradually visualized the participants' responses, which facilitated our research ("Barcelona Field Studies Centre", 2020-2021). At this point we want to stress that colour coding was chosen in each category individually and not as a whole in all data.

Regarding the nursery (pre-school) teachers we sought which teaching way-method was most frequently used according to their statements and six (6) methods emerged. For each one we used different colour or/and different marking, in order to manage analyzing and clearly state the results. Subsequently, as regards primary teachers eleven (11) ways-methods emerged, as regards IT (or Computing) teachers eight (8) ways-methods emerged and regarding secondary teachers five (5) ways-methods emerged. Finally, we designed bar charts for each specialty depending on participants' relevant answers (and their number).

Once we completed this process, we converted the colour coding to taxonomic coding. As Glesne (2018, p. 301) writes "there is no correct coding scheme", but if we had to include our coding somewhere, we would include it in taxonomic coding (Glesne, 2018). The purpose of this conversion was to make our research more reader friendly. The conversion of the coding was done in the following way: for each colour we used in each category (basic code), we created a subcode.

For example, our first category (code, as mentioned above) is the "Kindergarten teachers". Firstly, at this category (code) we highlighted Collaborative teaching/method answers with yellow colour and then we "converted" the yellow colour to the subcode "Collaborative teaching/learning". This subcode included all the answers that we had marked yellow referring to collaborative teaching/learning from the "Kindergarten teachers" code. This coding process was performed for all research participants' responses and in this way all the subcodes of the four (4) basic codes (Kindergarten teachers, Primary school teachers, Primary and Secondary school informatics teachers, Secondary school teachers) were created.

The answers of the interviewees were coded (Flick, 2017; Glesne, 2018; Isari \& Pourkos, 2015) in order to distinguish patterns (Glesne, 2018) and four (4) codes with their subcodes emerged. "A code is a word or a short phrase, not a combination of numbers / letters or a set of letters that represent a phrase" (Glesne, 2018, p. 297). We chose not to use abbreviations (acronyms) because according to Saldaña they appear not easy at decoding (Saldana, 2009).

We seeked through the literature (and try to sort of synthesize it) in order to try to answer our research question. Electronic journals were accessed through Scholar and we also used books that we own. We chose articles mainly published after 2010 (with some important exceptions). For most searches, we used one, two or three keywords (concurrently) (i.e., best*, best way*, best way teching*).

Our method is qualitative and the tools used adopt elements from semi-structured e-mail interviews and discourse analysis, since we interviewed the teachers but following we tried to analyse their words (each specialisation separately). The methodological tool of content analysis is defined as "the scientific study of content of communication" and refers to what is actually and deeply meant behind words and texts (Prasad, 2008, p. 1; Sriwimon \& Zilli, 2017) or as Fragoudaki concluded in 1979, it is a "pragmatic" method (Fragoudaki, 1979, p. 11) that treats any form of "text" as an object for research. Moreover, as regards semi-structured or unstructured interviews one has to keep in mind that they "may include only one or a few predetermined questions allowing the interviewer to explore issues brought forward by the interviewee" (McGrath, Palmgren, \& Liljedahl, 2019, p. 1003).

Interviews are of great interest to the researcher who uses them (Fink, 2000). But when interviewing one has to take into account that s/he should follow the interviewees' schedule and even sometimes the interviewees' expressed points of view (as researchers we may deal with the likelihood of correcting or counseling the participant etc.) (Qu \& Dumay, 2011; Gerard Forsey, 2010; Palys \& Lowman, 2006). Meanwhile, Bolderston (2012) reminds us that as researchers we are of direct necessity of them in order for the data to be gathered; we need persons who have the will and the experience to talk about what we are interested in studying.

Concerning e-mail interviewing, many writers have exalted the fact that these interviews (which are included in asynchronous communication schemes) have access to participants all over the world at the time and 
place that is convenient to them (Bampton \& Cowton, 2002; Bowker \& Tuffin, 2004; Coomber, 1997; Fritz \& Vandermause, 2018). Not to mention that e-mail interviews reduce cost (Fontes \& O'Mahony, 2008; Gibson, 2010), present more concrete answers (Kazmer \& Xie, 2008; Synnot, Hill, Summers, \& Taylor, 2014), participants may even feel authors of their own lives and get excited about it- (Gander et al., 2013; Gibson, 2010) and help participants talk about personal and more intimate issues (Deakin \& Wakefield, 2014); apart from offering them time to re-contemplate their answer and, moreover, the most appropriate "environmental" conditions (James, 2016; Opdenakker, 2006).

To make the long story short, "email interviews engage the full range of methodological and theoretical themes of qualitative research" (Burns, 2010, p. 5) and are increasingly and widely used to this end (Hawkins, 2018).

\subsection{Main Research}

In the following subchapters we list all the answers given by the participants of our research by code, using our individual coding. We also write the information we extracted from the analysis of these answers and encodedmanaged thereafter. More specifically, at the beginning of each subchapter we list the subcodes we created, then we quote a diagram (bar chart) that shows the frequency of appearance of these codes, followed by some of our own comments/remarks regarding the participants' answers and we close by citing them.

2.2.1 Kindergarten teachers (18 participants)

Collaborative learning/method

Empirical/Experiential learning/method

Cross-curricular / Interdisciplinary

Playful learning Differentiated teaching

Frontal learning

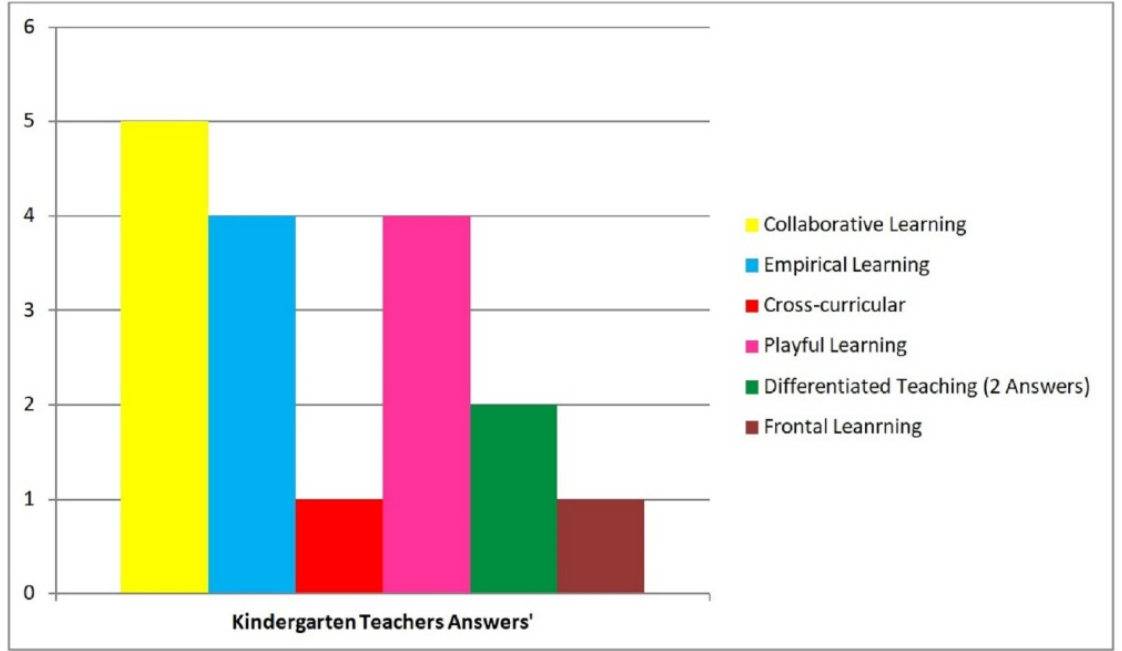

Figure 1. Frequency of responses. (Authors' own)

Frequency of each of the six (6) different answers.

In Figure 1 the frequency of each of the six (6) different answers is presented. The question was "Which is the most suitable way of teaching, according to your opinion?". The most common answer is "Collaborative Learning", then "Empirical and Playful Learning" follows and then "Differentiated Teaching". "Frontal Learning" and "Cross-curricular" come last.

Answers 6,8,11 are of special interest as they mention: supervisory means, PC, audiovisual.

Alike, answers 5, 9, 11, 17 are interesting as they mention: personality, peculiarities, needs etc of the pupils'/students' and answers 2, 9, 11, 12: experience/already existing knowledge, respectively.

According to authors' opinion, answers 1, 4, 6, 8, 9, 11 imply teachers' effort to stimulate children's interest. Answer 5 is the only one that includes the word empathy, answer 18 attracted our attention since it gives more importance to the kindergarten teacher than to children and answer 17 alone refers to the word constructivism -in word; although other teachers refer to the whole procedure of building on the existing knowledge.

Answers:

i. The most effective way of teaching is through the principles of collaborative teaching. Using working groups and sharing roles so that knowledge comes from the children and I have a helpful role when it is necessary (giving children the right material, tools, instructions and mainly trigger interest in the subject that we are interested in).

ii. The one who uses the chidren's experiences as a start and aims at the joint discovery of knowledge (pupil/student and teacher). As a method the bibliography suggests the collaborative teaching but from 


\section{iii. Collaborative.}

iv. An effective way of teaching is the collaborative method in which pupils/students are divided into small heterogeneous groups and work interactively and interdependently to achieve common goals.

v. Love what you do and feel empathy! Collaborative teaching is focusing on the pupil/student and her/his needs.

vi. I use a combination of experiential methods. I'm trying to get the kids to come in to contact with the objects they're going to use, for example, to take the books and search. I use it a lot in the educational process and the computer.

vii. Experiential.

viii. Experiential using audiovisual media as tools.

ix. I believe that experiential learning is the most effective, because it adapts to the needs, interests and experiences of children. Pupils/Students can observe, experiment, discover and develop problemsolving skills.

x. I work in a cross-curricular way I choose a theme e.g. "the water" and I work it separately for visual arts.

xi. I would say the one who starts from the child and her/his needs, from the pre-existing knowledge on which the future knowledge will later be built [...]. In order for teaching to be as effective as possible, various audiovisual teaching means should be used and anything able to be presented as a playful learning to the children!

xii. Playful learning combined with experiences, experience and collaboration within the group.

xiii. The one who helps the child to understand the new material and to assimilate it more easily. I think that if this is done in a playful way then it will be more effective.

xiv. In my opinion, the most appropriate way of teaching in kindergarten is the playful teaching

xv. Differentiated teaching.

xvi. Differentiated teaching through active participation of children and the creation of groups.

xvii. The one based on the theory of the constructivism [...]. Where teaching is done not through books and theories but through experiences and the active participation of the pupil/student. All this [...] respecting each pupil's/student's personality and special features.

xviii. The most effective way of teaching is the one through which the teaching goals are set by the teacher.

2.2.2 Primary school teachers (25 participants)

Collaborative Learning/Method

Empirical/Experiential learning/method

Traditional Way

Vygotsky

Differentiated Teaching

Projects

Constructive Frontal Learning

Personalized Learning

Student-Centred Teaching

Mixed Dialogue

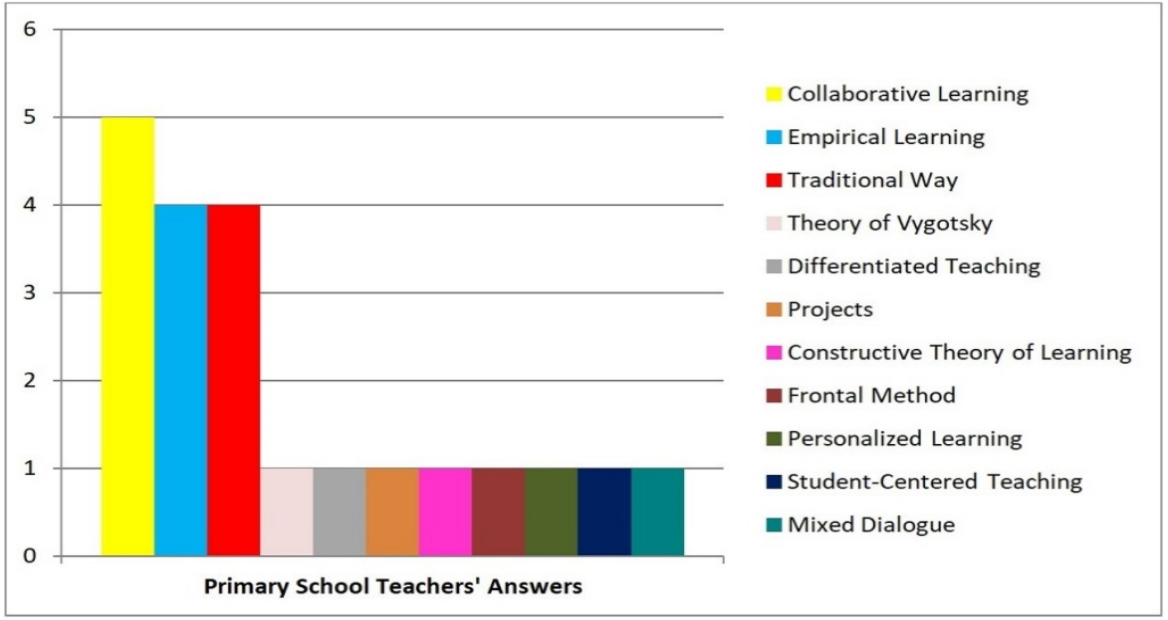

Figure 2. Frequency of responses. (Authors' own)

The answers that were given from twenty five primary school teachers.

At the right part of Figure 2 are listed the answers that were given from twenty five (25) primary school 
teachers on question "Which is the most suitable way of teaching, according to your opinion?". At the left part is presented each answer's frequency, respectively. It is evident that the most common answer is "Collaborative Learning".

Answers of special interest are: 13 as it mentions supervisory means and 19 for mentioning technology.

Alike, answer 2 is interesting, since we believe contradicts kindergarten teachers' answers; most of the latter chose "the group collaborative method", while in this answer it is mentioned that as regards group collaborative method "the younger the pupils/students, the more difficult it gets".

Finally, answers 6, 7, 8 and 9 are interesting for mentioning art and philosophy, educational drama, methodology of inadequacy (literal translation) and life skills.

Answer 1 depicts teacher's willingness to attract pupils'/students' interest, answer 4 mentions pleasure through learning, answer 12 shows preference in the use of blackboard, answers 13, 14, 15 introduce praisepenalty and answer 19 describes a combination of experiential learning and use of technology.

Before moving to the following parts we must point out the fact that answer 14 contradicts the traditional way of teaching (though via her/his answer it becomes obvious that $\mathrm{s} /$ he actually does believe that traditional teaching includes the elements $\mathrm{s} /$ he mentions).

Answers:

i. The most effective way is experiential teaching [...] For example I teach them the prepositions in grammar with rap songs, which may be close to their interests. When children themselves participate in the learning process, the results are better and teacher's work becomes easier.

ii. The effectiveness of teaching depends on the purposes and the type of lesson taught, the desired results and the age group of pupils/students. In any case, a collaborative method works well both for achieving cognitive goals, and for developing the ability to collaborate and co-exist in groups of pupils/students $[\ldots]$. The younger the pupils, the more difficult it gets.

iii. Applying Vygotsky's theory of social constructivism.

iv. The best way of teaching ensures, as much as possible, pleasure through learning and promotes autonomy and independence by reducing enforcement and coercion (as it happens sometimes with school work).

v. The best way of learning is to exploit each pupil's/student's special skills by ensuring personalized teaching $[\ldots]$.

vi. Exploiting art and philosophy (Discussions with children faced with dilemmas to enhance critical thinking).

vii. Integrating educational drama and creating emotional atmosphere in lessons.

viii. Cultivating skills that promote life skills e.g. pupils'/students' self-presentation.

ix. Not to use primarily the methodology of deficit: not to start from deficiencies and disturbances in order to see the causes of failure, as it is multifaceted.

x. Teaching with groups of pupils/students consisting of four to five pupils/students.

xi. Teaching which is based on the constructive theory of learning.

xii. The traditional way of teaching with desks in frontal order, with systematic teaching of Grammar, using the blackboard and not photocopies.

xiii. The traditional way of teaching and frontal learning. Focuses on the acquisition of cognitive and social goals. It is necessary to consider the use of audiovisual media for immediate acquisition.

xiv. Traditional way of teaching. Teacher assistant and observer. Freedom of expression for pupils/students. Reward-Penalties. Desks aligned in rows.

xv. Traditional Teaching: determining the role of the teacher, rewarding effort and setting boundaries.

xvi. The most appropriate way of teaching is experiential. Experiential learning is an alternative way of education that is beyond the desks, school books and memorization. [...] Children are actively involved in learning through questions and queries by working in groups.

xvii. The most appropriate way of teaching is the collaborative way, because it is the method that helps the pupil/student to self-act, to think. It promotes cooperation and dialogue between children...

xviii. The grouped collaborative method, because only through working in groups and collaboration we can make children learn to perform.

xix. Experiential way with the use of technology as a tool to achieve the goals set by the teacher.

$\mathrm{xx}$. Experiential learning

xxi. Differentiated teaching is a way of teaching that focuses on the pupil/student by treating her/him as a special personality in the process of learning. That's why I think it's the most appropriate.

xxii. Student-centered, teaching that places the pupil/student in the center using always dialogue as a way to achieve the goals set.

xxiii. Mixed dialogue: free dialogue directed by the educator, so as to limit negative points and to use it so as to reveal pupils'/students' learning benefit. 
xxiv. Teaching via projects with the participation of children in groups.

xxv. Group collaboration teaching.

2.2.3 Primary and secondary school informatics teachers (14 participants)

Student - Centred Way

Group Collaboration Teaching

Worksheets

Role Games

Theory Presentation

Interactive Way

Apocalyptic Learning

Other Teaching Ways

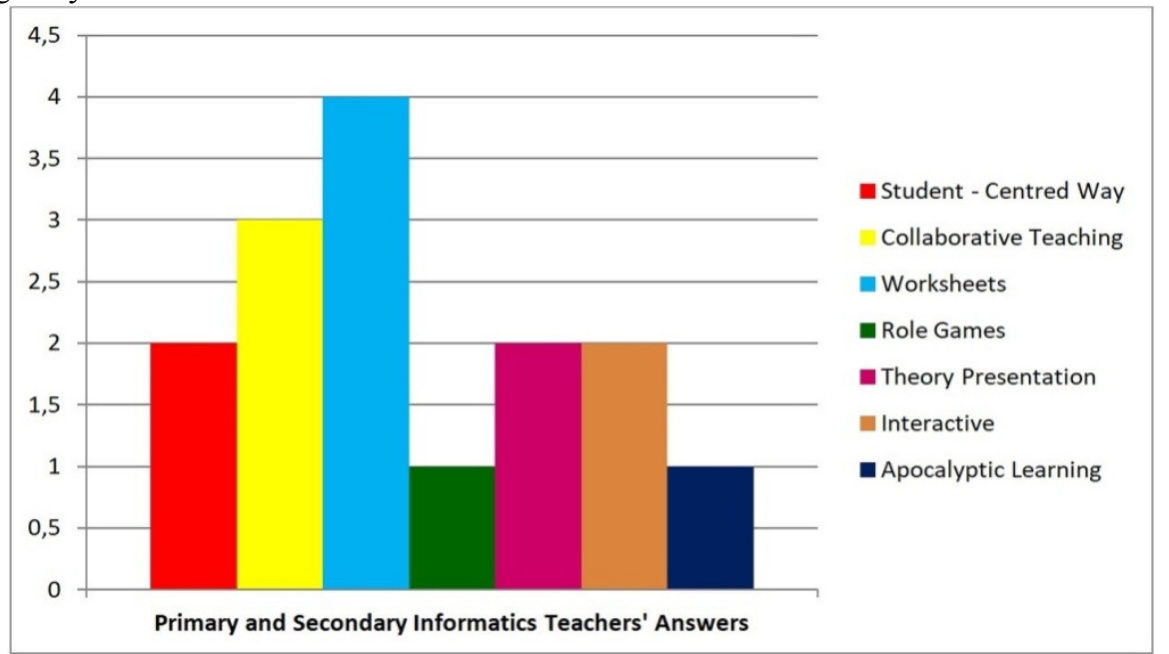

Figure 3. Frequency of responses. (Authors' own)

The frequency of each answer given from fourteen IT teachers.

In Figure 3 the frequency of each answer given from fourteen (14) IT teachers working in primary and secondary education is presented. The question was "Which is the most suitable way of teaching, according to your opinion?". We observe that the most common answer is "Worksheets".

Special attention should be given to answers 6 and 12 refer to circumstances and how much they define the proper way of teaching; and the fact that no one refers to the term "Information and Communication Technology (I.C.T)". The most intriguing answer is number 11, since the educatore teaches computer science mainly without using computers. At this point we want to emphasize that according to the instructions for the Informatics course (given from the Greek Ministry of Education), teaching is carried out mainly with the use of computers.

Answers:

i. Apocalyptic learning

ii. Student - Centred method

iii. Student - Centred method, group collaboration teaching, worksheets role games

iv. Teaching in the laboratory with 2 pupils/students per pc, worksheets.

v. The interactive way. Participation of pupils/students in the educational process.

vi. The most effective way of teaching is the one that focuses on pupil's/student's insufficiencies/deficiencies, needs and interests.

vii. Theory presentation with worksheets, power points and pupil/student participation.

viii. Presentation and worksheets.

ix. Interactive.

x. The teaching method should pay attention to synthetic and collaborative work.

xi. Creation of learning scenarios through games (mainly without the use of PC) with all pupils'/students' active participation.

xii. Depends on the lesson. For example, in IT applications I follow exploratory learning, guiding pupils/students to discover their own knowledge. In Programming I choose a mixed model.

xiii. Teaching that focuses on pupils/students and specifically teaching in groups.

xiv. With use of video projector and check of the workstations. 
2.2.4. Secondary school teachers

Student - Centered Teaching

Frontal Learning

"Voice thought"

Empirical-Experiential learning/method

Interactive

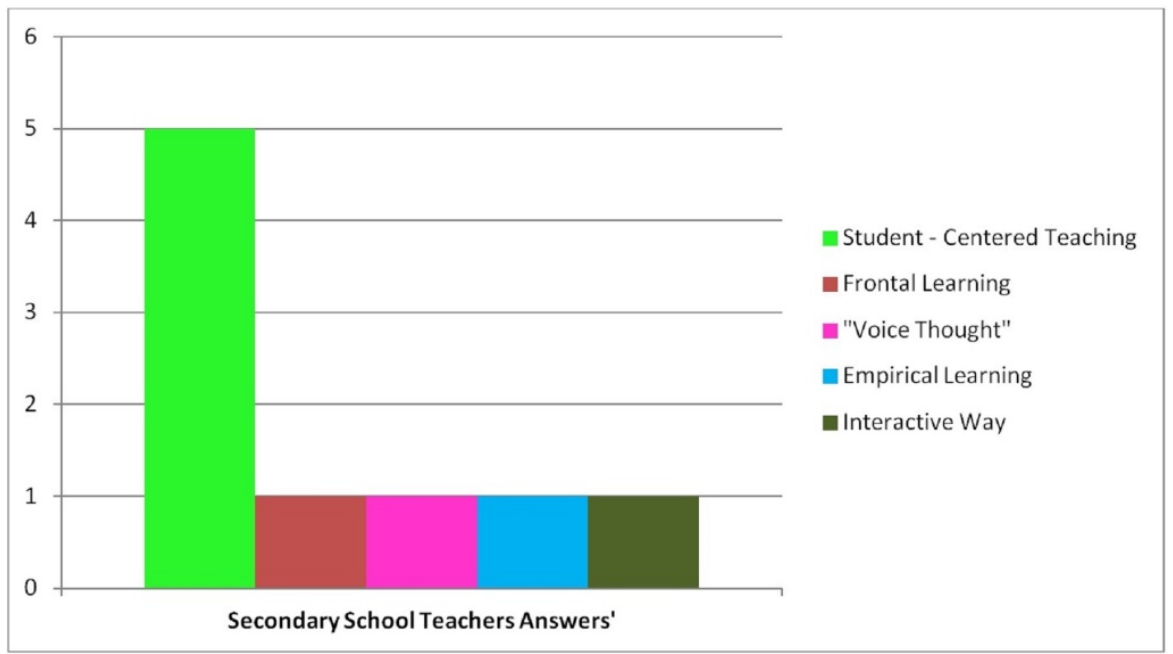

Figure 4. Frequency of responses. (Authors' own)

The frequency of each of the five different answers given from secondary school teachers.

In Figure 4 the frequency of each of the five (5) different answers given from secondary school teachers is presented. The question was "Which is the most suitable way of teaching, according to your opinion?". The most common answer is "Student-Centered Teaching" and the answers (which appear one time each), "Empirical Learning", "Frontal Learning", "Interactive Way", "Voice Thought" followed.

Answers 1 and 4 state that the proper way of teaching depends on the circumstances, answer 9 and 4 mentions audiovisual media and answer 7 seems very general, since "voice thought" can only be analyzed via personal contemplation.

Answers:

i. The way of teaching depends solely on the particular circumstances prevailing in the classroom. [...] The aim is to activate and motivate pupils/students to participate and export the basic concepts as if it is a matter of cooperative process, -at least the largest part of the classroom.

ii. Probably the most effective way of teaching is the student-centered, interactive way.

iii. The method derived from Student-Centered (student-centric) teaching and uses dialogue as the main tool.

iv. Because teaching is a complex process, its effectiveness, I think does not depend on the application of a specific way. In my opinion, teacher needs to be flexible [...] traditional ways of teaching are combined with the power of modern audio-visual media, experiential learning [...].

v. Frontal teaching... With images.

vi. The effective way of teaching and learning is important to focus on the pupil/student throughout various methods which will be initiated into knowledge.

vii. I believe that the "Voice thought" teaching model encourages pupils/students to illustrate their own strategy and way of thinking.

viii. Not the teacher-centric. We leave initiatives for action and participation by children and we offer them the trigger.

ix. Experiential method with the use of audiovisual media.

\section{Results}

As Pološki Vokić \& Aleksić (2020, p. 9) wrote "It is therefore recommended to educators to use various strategies when they teach, in order to provide a learning context that will be the most beneficial one for diverse types of learners" and this provides us with an answer regarding our participants' responses; why they differ (though the most common is collaborative teaching/method). The writers continue to state that educators choose to motivate their students to express the way they learn and be active as regards their teaching in order for the whole procedure to be more effective for them. The same argument ("to take a more active part") is raised by Bovill, Cook - Sather \& Felten (2011, p.143).

Expressing themselves in many ways teachers ended up stating that the most suitable way of teaching -and 
also the one most commonly used- is Group collaborative teaching/learning. Of course opinions regarding Collaborative teaching/learning (González \& Muñoz-Repiso, 2017; Kumi-Yeboah, Dogbey, \& Yuan, 2017; Stahl, Koschmann, \& Suthers, 2006; Dillenbourg, 1999), Empirical learning/method (see also Valovičová \& Sollárová, 2017), Experiential learning/method (Kolb \& Kolb, 2017; McCarthy, 2016; Rendell \& Cho, 1990), Traditional way (Black \& Roberts, 2006), Differentiated Teaching (Tulbure, 2011), Constructive learning (Naif \& Atia, 2020; Damnik, Proske, \& Körndle, 2017; Vermunt, 1998), "Frontal learning", Personalized learning (Heller, Steiner, Hockemeyer, \& Albert, 2006; McLoughlin \& Lee, 2010), Student-Centred Way (Czajka \& McConnell, 2019; Emaliana, 2017; Estes, 2004), Role playing (Tsergas \& Fragkos, 2021; Epstein, 2013), Theory presentation (Qu \& Teng, 2019; Butko, 2019), Interactive way (Yarmatov \& Ahmedova, 2020; Бульвінська \& Ханикіна, 2019; Sessoms, 2008), “Apocalyptic learning” were heard (please, when reading the text, be aware of the translation's needed "inquisitions"; some terms are not easily translated and even when we literally translate them we still can' $t$ find the real conception hiding in interviees' responds). One answer, teaching Computer Science/IT without using computers (Nagy, 2020; Johnson et al., 2019; Bell, Alexander, Freeman, \& Grimley, 2008; Pollard \& Forbes, 2003), needs also enlightenment cause its very special and unique, since it reminds us that Computer Science/IT is Science (Salatino, Thanapalasingam, Mannocci, Osborne, \& Motta, 2018; EfrosyniAlkisti Paraskevopoulou-Kollia et al., 2018; Denning, 2005; Forsythe, Keenan, Organick, \& Stenberg, 1969). But what was also heard is communicating with pupils/students, encouraging them and offering them knowledge, helping them become confident human beings (see also Murillo-Zamorano, Sánchez, \& Godoy-Caballero, 2019; Fang \& Cao, 2016; Thiry, Laursen, \& Hunter, 2011; Siegle \& McCoach, 2005).

\section{Discussion}

The teaching and learning process has changed and is constantly being changed through teachers' personal experiences, beliefs and opinions and, undoubtedly, through the characteristics of the society in which it takes place. Within the teaching field there is a strong possibility one not to be able to choose between definitions and teaching techniques, methods and practices. We often, though, observe the following phenomenon: a gap between officially formulated goals and expectations regarding cognitive subjects and their implementation which proves inadequate with poor acceptance by the school community. For all the above mentioned reasons we tried to seek educators' points of view on teaching methods and processes.

Even though the answers were not exactly similar, one could claim that a lot of teachers (of our sample) try to match their teaching method to pupils' needs, as they quoted, and that is as essential and strong element as the answer which was mostly mentioned (Group collaborative teaching/learning). While teaching, the methods used are combined with personal notions and decisions and teachers are maestros of their classrooms and undoubtedly their thoughts. Of course, we should remember that there is always will and try.

Zeichner \& Liston wrote $(2013$, p. x) that “...we are educators first, realists second, and dreamers third. It is our firm belief that an education that engages prospective and practicing teachers' heads and hearts, their beliefs and passions, their hopes and instructional practices needs to be fair and honest". This is one of the main reasons why we asked educators to freely express themselves on what practices and techniques they follow in the classroom within specific educational system. We would like to mention that our research could be conducted in the future with new and larger sample and be strengthened -as regards literacy- to ensure its validity.

The writers also reminded us the crucial role that cultural environment and its components and insights play regarding teachers and students (Zeichner \& Liston, 2013). Cultural environment needs to be understood first, in order to prepare both sides (teachers and students) fairly and efficiently. Apart from cultural background, the local background also plays a role. The local background is one of the main factors that guide and ultimately determine techniques that vary according to students' needs (see also Martin et al., 2014; Manca \& Ranieri, 2013; Hlebowitsh, 2012) and personal characteristics (Pološki Vokić \& Aleksić, 2020). Teachers -in a rapidly changing world- seek to find elements that would match their students' interests (see also Twenge, 2013). Thus there cannot be a "best" teaching method. It is not possible to have an objectively "optimal" theory, against which educators can compare the ones developed by themselves (see also Hlebowitsh, 2012, p. 3). As Zeichner \& Liston (2013) mentioned there are many inceptions of how teaching could be effective (see also Shukla, Dosaya, Nirban, \& Vavilala, 2020; Oder \& Eisenschmidt, 2018; Ginting, 2017).

\section{Conclusion}

This work aimed to explore the educational process through teachers' point of view and actions on a daily basis. Nursery, primary and secondary school teachers, as well as IT teachers were asked one question ("Which is the most suitable way of teaching, according to your opinion?"), in order for the main result to come about. As a concluding argument, we have to admit that looking the subject from a wider point of view, what could have been done is to also explore teachers' opinions and experiences on more questions on the same theme. Thus, much greater effort should be made in doing research beyond purely educational teaching activities, in order to highlight more realistic educational situations during teaching so as to enlighten educators' efforts. Apart from 
that, more research and discussion by theorists and researchers seems indispensable, in order to compare current education in relation to different educational systems and evaluate existing and frequently used teaching techniques in the light of pioneering and more diversed teaching techniques. We focused on the most striking differences and similarities that arose from the sixty six (66) answers given to the question that we posed in total. At this point we have to highlight that the conclusions of this research are difficult to generalize, as they concern a limited number of participants (66 persons) who agreed to engage in it and answer a very specific question (Baker \& Edwards, 2012; Ercikan \& Roth, 2014).

\section{References}

Athanasiou, K. (2015). Teaching Biology [Didaktiki tis biologias] Retrieved from http://hdl.handle.net/11419/4794

Baker, S. E., \& Edwards, R. (2012). How many qualitative interviews is enough.

Bambaeeroo, F., \& Shokrpour, N. (2017). The impact of the teachers' non-verbal communication on success in teaching. Journal of advances in medical education \& professionalism, 5(2), 51

Bampton, R., \& Cowton, C. J. (2002). The e-interview. Paper presented at the Forum qualitative sozialforschung/forum: Qualitative social research.

Barcelona Field Studies Centre. (2020-2021). Retrieved 15/05/2021, 2021, from https:/geographyfieldwork.com/pdf/CodingAnalysisExample.pdf

Bell, T., Alexander, J., Freeman, I., \& Grimley, M. (2008). Computer science without computers: new outreach methods from old tricks. Paper presented at the Proceedings of the 21 st annual conference of the national advisory committee on computing qualifications.

Black, C., \& Roberts, S. (2006). Learning the social way: Enhancing learning in a traditional setting. New Review of Academic Librarianship, 12(2), 83-93.

Bolderston, A. (2012). Conducting a research interview. Journal of Medical Imaging and Radiation Sciences, 43(1), 66-76.

Bovill, C., Cook - Sather, A., \& Felten, P. (2011). Students as co - creators of teaching approaches, course design, and curricula: implications for academic developers. International Journal for Academic Development, 16(2), 133-145.

Bowker, N., \& Tuffin, K. (2004). Using the online medium for discursive research about people with disabilities. Social Science Computer Review, 22(2), 228-241.

Brookhart, S. M. (2011). Educational assessment knowledge and skills for teachers. Educational Measurement: Issues and Practice, 30(1), 3-12.

Bukor, E. (2015). Exploring teacher identity from a holistic perspective: Reconstructing and reconnecting personal and professional selves. Teachers and Teaching, 21(3), 305-327.

Burns, E. (2010). Developing email interview practices in qualitative research. Sociological research online, 15(4), 1-12.

Butko, S. S. (2019). Visual materials and their presentation in teaching English to hearing impaired students. Педагогический журнал, 9(6-1), 120-124.

Canevaro, L. G., \& O’Rourke, D. (2020). Didactic Poetry of Greece, Rome and Beyond: Knowledge, Power, Tradition, The Classical Press of Wales, Swansea 2019, 307 pp.; ISBN 978-1-910589-79-3. ELECTRUM, $27,239$.

Cavanaugh, C., Dawson, K., \& Ritzhaupt, A. (2011). An evaluation of the conditions, processes, and consequences of laptop computing in K-12 classrooms. Journal of Educational Computing Research, 45(3), 359-378.

Cochran-Smith, M., \& Fries, M. K. (2001). Sticks, stones, and ideology: The discourse of reform in teacher education. Educational researcher, 30(8), 3-15.

Coomber, R. (1997). Using the Internet for survey research. Sociological research online, 2(2), 49-58.

Czajka, C. D., \& McConnell, D. (2019). The adoption of student-centered teaching materials as a professional development experience for college faculty. International Journal of Science Education, 41(5), 693-711.

Damnik, G., Proske, A., \& Körndle, H. (2017). Designing a constructive learning activity with interactive elements: the effects of perspective-shifting and the quality of source material. Interactive Learning Environments, 25(5), 634-649.

Deakin, H., \& Wakefield, K. (2014). Skype interviewing: Reflections of two PhD researchers. Qualitative research, 14(5), 603-616.

Denning, P. J. (2005). Is computer science science?(Spanish version). Communications of the ACM, 48(4), $27-$ 31.

Dillenbourg, P. (1999). What do you mean by collaborative learning? Collaborativelearning: Cognitive and Computational Approaches. Oxford: Elsevier, 1-19.

Dimitriadou, K. (2016). New Orientations to Teaching. Responding to the Educational Challenges of 21st 
Century. Athens: Gutenberg.

D’Souza, M. S., Nikku, B. R., \& Field, C. (2021). Interdisciplinary teaching practices: Reflections from a teaching triangle. Journal of Nursing Education and Practice, 11(5).

Emaliana, I. (2017). Teacher-centered or student-centered learning approach to promote learning?. Jurnal Sosial Humaniora (JSH), 10(2), 59-70.

Epstein, S. E. (2013). What is my role? Establishing teacher and youth worker responsibilities in social action projects. Teachers and Teaching, 19(5), 492-506.

Ercikan, K., \& Roth, W.-M. (2014). Limits of generalizing in education research: Why criteria for research generalization should include population heterogeneity and uses of knowledge claims. Teachers College Record, 116(5), 1-28.

Errington, E. (2004). The impact of teacher beliefs on flexible learning innovation: some practices and possibilities for academic developers. Innovations in education and teaching international, 41(1), 39-47.

Estes, C. A. (2004). Promoting student-centered learning in experiential education. Journal of Experiential Education, 27(2), 141-160.

Fang, H., \& Cao, Q. (2016, April). Appreciation Makes Students Grow Healthy and Self-confident. In Proceedings of the 6th International Conference on Electronic, Mechanical, Information and Management Society.

Fairman, J. (2004). Trading roles: Teachers and students learn with technology. Paper presented at the annual conference of the New England Educational Research Organization, Portsmouth, NH.

Federici, E., Russo, C., Tafuri, F., \& Pezzella, A. R. (2021). Special Educational Need (SEN): An innovative Didactic Approach. International Journal of Education and Evaluation, 7.

Fink, A. S. (2000). The role of the researcher in the qualitative research process. A potential barrier to archiving qualitative data. Paper presented at the Forum qualitative sozialforschung/forum: Qualitative social research.

Fletcher, J., Mackey, J., \& Fickel, L. (2017). A New Zealand case study: What is happening to lead changes to effective co-teaching in flexible learning spaces?. Journal of Educational Leadership, Policy and Practice.

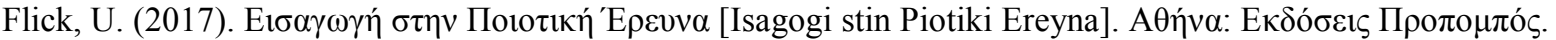

Fontes, T. O., \& O’Mahony, M. (2008). In-depth interviewing by Instant Messaging. Social research update, $53(2), 1-4$

Forsythe, A. I., Keenan, T., Organick, E., \& Stenberg, W. (1969). Computers Science: Wiley.

Fragoudaki, A. (1979). Ta anagnostika vivlia tou dimotikou scholiou. Ideologikos periorismos kai paidagogiki via [Primary education's school books. Ideological constraint and educational violence]. Athens: Themelio.

Friesen, N., \& Osguthorpe, R. (2018). Tact and the pedagogical triangle: The authenticity of teachers in relation. Teaching and Teacher Education, 70, 255-264

Fritz, R. L., \& Vandermause, R. (2018). Data collection via in-depth email interviewing: Lessons from the field. Qualitative Health Research, 28(10), 1640-1649.

Fullan, M. G. (1993). Why teachers must become change agents. Educational leadership, 50, 12-12.

Gander, W., Petit, A., Berry, G., Demo, B., Vahrenhold, J., McGettrick, A., . . Ghezzi, C. (2013). Informatics education: Europe cannot afford to miss the boat. Report of the joint Informatics Europe \& ACM Europe Working Group on Informatics Education.

Geddis, A. N. (1993). Transforming subject - matter knowledge: the role of pedagogical content knowledge in learning to reflect on teaching. International Journal of Science Education, 15(6), 673-683.

Gerard Forsey, M. (2010). Ethnography as participant listening. Ethnography, 11(4), 558-572.

Gibson, L. (2010). Realities toolkit: Using email interviews. ERSC National Center for Research Methods, 1-7.

Ginting, S. A. (2017). A Facilitating Effective Teaching through Learning Based on Learning Styles and Ways of Thinking. Dinamika Ilmu, 17(2), 165-173.

Glesne, C. (2018). Becoming Qualitative Researchers: An Introduction [I Piotiki Ereyna Odigos gia neous epistimones] (Vol. 1). Athens, Greece: METAIXMIO.

González, Y. A. C., \& Muñoz-Repiso, A. G. V. (2017, October). Development of computational thinking and collaborative learning in kindergarten using programmable educational robots: A teacher training experience. In Proceedings of the 5th International Conference on Technological Ecosystems for Enhancing Multiculturality (pp. 1-6).

Grando, G., Bramuzzo, S., Irato, P., Guidolin, L., Ferrari, L., \& Santovito, G. (2018). Introduction to the world of insects: a didactic research in kindergarten. INTED2018 Proceedings.

Green, K. (2000). Exploring the everyday'philosophies' of physical education teachers from a sociological perspective. Sport, Education and Society, 5(2), 109-129.

Hawkins, J. E. (2018). The practical utility and suitability of email interviews in qualitative research. The Qualitative Report, 23(2), 493-501.

Handayani, N. (2017, April). Becoming the Effective English Teachers in the 21st Century: What Should Know and What Should Do?. In English Language and Literature International Conference (ELLiC) Proceedings 
(Vol. 1, pp. 156-164).

Heller, J., Steiner, C., Hockemeyer, C., \& Albert, D. (2006). Competence-based knowledge structures for personalised learning. International Journal on E-learning, 5(1), 75-88.

Hlebowitsh, P. (2012). When best practices aren't: A Schwabian perspective on teaching. Journal of Curriculum Studies, 44(1), 1-12.

Isari, F., \& Pourkos, M. (2015). Qualitative research methodology [Piotiki methodologia erevnas] Retrieved from http://hdl.handle.net/11419/5826

James, N. (2016). Using email interviews in qualitative educational research: Creating space to think and time to talk. International Journal of Qualitative Studies in Education, 29(2), 150-163.

Jernes, M., Knaben, Å. D., Tungland, I. B. E., \& Alvestad, M. (2020). Pedagogy and interdisciplinarity: Research on the reformed kindergarten teacher education (KTE) in Norway. Cogent Education, 7(1), 1707519.

Johnson, H., McNally, S., Rolfe, H., Ruiz-Valenzuela, J., Savage, R., Vousden, J., \& Wood, C. (2019). Teaching assistants, computers and classroom management. Labour Economics, 58, 21-36.

Kazmer, M. M., \& Xie, B. (2008). Qualitative interviewing in Internet studies: Playing with the media, playing with the method. Information, Community and Society, 11(2), 257-278.

Kazu, İ. Y., \& Issaku, Y. (2021). The opinion of ELT students on technology-based classroom approach. Focus on ELT Journal, 3(1), 33-42.

Komis, V. (2004). Introduction in educational applications of ICT [Isagogi stis ekpedeytikes efarmoges ton Technologion tis Pliroforias ke ton Epikinonion]. Athens: Ekdoseis Neon technologion.

Komis, V. (2006). Introduction in teaching Informatics [Isagogi sti Didaktiki tis Pliroforikis]. Athens: Kleidarithmos.

Kolb, A. Y., \& Kolb, D. A. (2017). Experiential learning theory as a guide for experiential educators in higher education. Experiential Learning \& Teaching in Higher Education, 1(1), 7-44.

Kumi-Yeboah, A., Dogbey, J., \& Yuan, G. (2017). Online collaborative learning activities: The perspectives of minority graduate students. Online Learning Journal, 21(4).

Lazar, S. (2015). The importance of educational technology in teaching. International Journal of Cognitive Research in Science, Engineering and Education, 3(1).

Maaranen, K., \& Stenberg, K. (2020). Making beliefs explicit-student teachers' identity development through personal practical theories. Journal of Education for Teaching, 46(3), 336-350.

Manca, S., \& Ranieri, M. (2013). Is it a tool suitable for learning? A critical review of the literature on F acebook as a technology - enhanced learning environment. Journal of Computer Assisted Learning, 29(6), 487-504.

Markham, A. N. (2019). Critical pedagogy as a response to datafication. Qualitative Inquiry, 25(8), 754-760.

Martin, B. O., Kolomitro, K., \& Lam, T. C. (2014). Training methods: A review and analysis. Human Resource Development Review, 13(1), 11-35.

Matsagouras, I. (2006). Theory and praxis of teaching. [Theoria ke praxi tis didaskalias] (Vol. A). Athens: Gutenberg - George \& Kostas Dardanos.

McCarthy, M. (2016). Experiential learning theory: From theory to practice. Journal of Business \& Economics Research (JBER), 14(3), 91-100.

McBer, H. (2001). Research into teacher effectiveness. Early Professional Development Of Teachers, 68(216), $1-69$.

McGrath, C., Palmgren, P. J., \& Liljedahl, M. (2019). Twelve tips for conducting qualitative research interviews. Medical teacher, 41(9), 1002-1006.

McLoughlin, C., \& Lee, M. J. (2010). Personalised and self regulated learning in the Web 2.0 era: International exemplars of innovative pedagogy using social software. Australasian Journal of Educational Technology, 26(1).

Mpotsoglou, K., Kakana, D., \& Chatzopoulou, K. (2007). Modern forms of teaching and learning. Views of preschool educators on collaborative teaching. [Sigxrones morfes didaskalias kai mathisis. Apopsis ton paidagogon tis prosxolikis ilikias gia tin omadosinergatiki.]. Exploring the child's world [Ereynontas ton kosmo toy paidioy], 7, 87-100.

Murillo-Zamorano, L. R., Sánchez, J. Á. L., \& Godoy-Caballero, A. L. (2019). How the flipped classroom affects knowledge, skills, and engagement in higher education: Effects on students' satisfaction. Computers \& Education, 141, 103608.

Nagy, A. (2020). Computer Science without Computers: A Guide to Teaching Concepts of Computer Science without Access to Computers or Other Technological Devices. DePauw University, Scholarly and $\mathrm{Cr}$ Scholarly and Creative Work from DePauw University.

Naif, A. S., \& Atia, M. A. H. (2020). The Effect of Constructive Learning Model on Cognitive Achievement and Learning dribbling Skill in Soccer for Secondary School Students. journal of physical education, 32(2).

Oder, T., \& Eisenschmidt, E. (2018). Teachers' perceptions of school climate as an indicator of their beliefs of 
effective teaching. Cambridge Journal of Education, 48(1), 3-20.

Opdenakker, R. (2006). Advantages and disadvantages of four interview techniques in qualitative research. Forum qualitative sozialforschung/forum: Qualitative social research, 7(4).

Palys, T., \& Lowman, J. (2006). Protecting research confidentiality: Towards a research-participant shield law. Canadian Journal of Law \& Society/La Revue Canadienne Droit et Société, 21(1), 163-185.

Panzavecchia, M. (2020). In Other Words: Maltese Primary School Teachers' Perceptions of Cross-linguistic Practices and Flexible Language Pedagogies in Bilingual and Multilingual English Language Classes (Doctoral dissertation, University of Sheffield).

Papageorgiou, I. (2015). Sampling theory [Theoria digmatolipsias] Retrieved from http://hdl.handle.net/11419/1296

Paraskevopoulou-Kollia, E.-A. (2016). Teaching philosophy to non-philosophers. Thessaloniki: Afoi Kyriakidi. Thessaloniki: Afoi Kyriakidi.

Paraskevopoulou-Kollia, E.-A., Soursou, G., Zogopoulos, B., Oreopoulou, E., Kontou, P., \& Zoura, V. (2018). Computer Science Students' Views on Educational Studies-Pedagogy. Journal of Educational Technology, $15(1), 40-52$.

Parr, C. S., Wilson, M. N., Leary, M. P., Schulz, K. S., Lans, M. K., Walley, M. L., . . Studer, M. M. (2014). The encyclopedia of life v2: providing global access to knowledge about life on earth. Biodiversity data journal(2).

Pollard, S., \& Forbes, J. (2003). Hands-on labs without computers. ACM SIGCSE Bulletin, 35(1), 296-300.

Pološki Vokić, N., \& Aleksić, A. (2020). Are Active Teaching Methods Suitable for All Generation Y students?-Creativity as a Needed Ingredient and the Role of Learning Style. Education Sciences, 10(4), 87.

Prasad, B. D. (2008). Content analysis. Research methods for social work, 5, 1-20.

Qu, S. Q., \& Dumay, J. (2011). The qualitative research interview. Qualitative research in accounting \& management, 8(3), 238-264.

Qu, W., \& Teng, Y. (2019, July). Exploration and Research on Oral Presentation in Classroom Teaching in Foreign Language Teaching. In 4th International Conference on Contemporary Education, Social Sciences and Humanities (ICCESSH 2019) (pp. 533-537). Atlantis Press.

Rendell, L., \& Cho, H. (1990). Empirical learning as a function of concept character. Machine Learning, 5(3), 267-298

Retnawati, H., Djidu, H., Kartianom, A., \& Anazifa, R. D. (2018). Teachers' knowledge about higher-order thinking skills and its learning strategy. Problems of Education in the 21st Century, 76(2), 215

Rodd, P., \& Sanders, K. (2018). The imperative of critical pedagogy in times of cultural austerity: A case study of the capacity to reimagine education as a tool for emancipation. New Zealand Sociology, 33(3), 33-55.

Sajjad, S. (2010). Effective teaching methods at higher education level. Pakistan Journal of Special Education, $11,29-43$

Saldana, J. (2009). The Coding Manual for Qualitative Researchers. London: SAGE.

Salatino, A. A., Thanapalasingam, T., Mannocci, A., Osborne, F., \& Motta, E. (2018, October). The computer science ontology: a large-scale taxonomy of research areas. In International Semantic Web Conference (pp. 187-205). Springer, Cham.

Sessoms, D. (2008). Interactive instruction: Creating interactive learning environments through tomorrow's teachers. International Journal of Technology in Teaching and Learning, 4(2), 86-96.

Shukla, T., Dosaya, D., Nirban, V. S., \& Vavilala, M. P. (2020). Factors extraction of effective teaching-learning in online and conventional classrooms. International Journal of Information and Education Technology, $10(6), 422-427$

Siegle, D., \& McCoach, D. B. (2005). Making a difference: Motivating gifted students who are not achieving. Teaching exceptional children, 38(1), 22-27.

Sleeter, C. E., \& McLaren, P. E. (1995). Multicultural education, critical pedagogy, and the politics of difference. SUNY Press.

Solano, L., Cabrera, P., Ulehlova, E., \& Espinoza, V. (2017). Exploring the Use of Educational Technology in EFL Teaching: A Case Study of Primary Education in the South Region of Ecuador. Teaching English with technology, 17(2), 77-86.

Sriwimon, L., \& Zilli, P. J. (2017). Applying Critical Discourse Analysis as a conceptual framework for investigating gender stereotypes in political media discourse. Kasetsart Journal of Social Sciences, 38(2), 136-142.

Stahl, G., Koschmann, T. D., \& Suthers, D. D. (2006). CSCL: An historical perspective.

Stigler, J. W., \& Hiebert, J. (2009). Closing the teaching gap. Phi Delta Kappan, 91(3), 32-37.

Stovall, D. (2006). We can relate: Hip-hop culture, critical pedagogy, and the secondary classroom. Urban Education, 41(6), 585-602.

Strier, R., \& Shechter, D. (2016). Visualizing access: Knowledge development in university-community 
partnerships. Higher Education, 71(3), 343-359.

Synnot, A., Hill, S., Summers, M., \& Taylor, M. (2014). Comparing face-to-face and online qualitative research with people with multiple sclerosis. Qualitative Health Research, 24(3), 431-438.

Taylor, E., Breed, M., Hauman, I., \& Homann, A. (2013). Choosing Learning Methods Suitable for Teaching and Learning in Computer Science. International Association for Development of the Information Society.

Tejedor, G., Segalàs, J., Barrón, Á., Fernández-Morilla, M., Fuertes, M. T., Ruiz-Morales, J., . . Hernández, À. (2019). Didactic strategies to promote competencies in sustainability. Sustainability, 11(7), 2086.

Thiry, H., Laursen, S. L., \& Hunter, A.-B. (2011). What experiences help students become scientists? A comparative study of research and other sources of personal and professional gains for STEM undergraduates. The Journal of Higher Education, 82(4), 357-388.

Tsergas, N., \& Fragkos, S. (2021). Role-Playing as a Method of Teaching Social Sciences to Limit Bias and Discrimination in the School Environment. Journal of Education \& Social Policy Vol. 8, No. 2, June 2021.

Tulbure, C. (2011). Do different learning styles require differentiated teaching strategies? Procedia-Social and Behavioral Sciences, 11, 155-159.

Twenge, J. M. (2013). Teaching generation me. Teaching of Psychology, 40(1), 66-69.

Uljens, M. (2004). School didactics and learning: A school didactic model framing an analysis of pedagogical implications of learning theory: Psychology Press.

Valovičová, L', \& Sollárová, E. (2017, January). Empirical learning of children at kindergartens. In AIP Conference Proceedings (Vol. 1804, No. 1, p. 050008). AIP Publishing LLC.

Van der Heijden, H., Geldens, J. J., Beijaard, D., \& Popeijus, H. L. (2015). Characteristics of teachers as change agents. Teachers and Teaching, 21(6), 681-699.

Vermunt, J. D. (1998). The regulation of constructive learning processes. British journal of educational psychology, 68(2), 149-171.

Vosniadou, S., De Corte, E., Mandl, H., \& Glaser, R. (1996). International perspectives on the design of technology-supported learning environments: Routledge.

Windschitl, M., \& Sahl, K. (2002). Tracing teachers' use of technology in a laptop computer school: The interplay of teacher beliefs, social dynamics, and institutional culture. American educational research journal, 39(1), 165-205.

Yarmatov, R., \& Ahmedova, M. (2020). The role of methodology in teaching English to prospective teachers. Архив Научных Публикаций JSPI, 1-7.

Zeichner, K. M., \& Liston, D. P. (2013). Reflective teaching: An introduction: Routledge.

Zuo, Z., \& Zhao, K. (2018). The more multidisciplinary the better?-The prevalence and interdisciplinarity of research collaborations in multidisciplinary institutions. Journal of Informetrics, 12(3), 736-756.

Бульвінська, О., \& Ханикіна, Н. (2019). Interactive methods in communicative education. Неперервна професійна освіта: теорія і практика, (4), 68-73. 